\title{
An unconventional approach to integrated ground and surface water development
}

\author{
ROGER REVELLE and V LAKSHMINARAYANA* \\ Department of Political Science, University of California, San Diego, California 92093, USA \\ *Department of Civil Engineering, Indian Institute of Technology, Kanpur 208 016, India
}

\begin{abstract}
The conjunctive use of surface water with groundwater development in the Ganga Basin is considered more desirable due to unacceptable environmental conditions created by using all the low flows and the limited possibilities of surface storages. There are several ways to increase infiltration during the monsoon season. One method is to create groundwater storage by pumping during the non-monsoon period. A procedure for estimating the extent and the rate of pumping such that it is replenished in 120 days of the monsoon season and equilibrium is achieved, is outlined in this study. The areas in the Ganga Basin suitable for such groundwater storage schemes have been marked out and the economic aspects of the scheme have also been studied. It is concluded that with this scheme of underground storage of flood water the total potential irrigation in the Ganga Basin may be limited by the area of irrigable land rather than the water supply.

It is suggested that this potentially advantageous scheme should be systematically studied and investigated in detail and factors like sediment transportation which may reduce the infiltration rate, the possible hazards of subsidence due to lowering of the water table, the possible ecological effects, and other relevant issues should also be considered.
\end{abstract}

Keywords. Groundwater; conjunctive use; surface water; underground water storage.

\section{Introduction}

The various Ganga models have suggested that large increases in irrigated area are only obtained at the expense of good low flow conditions. Deteriorating low flow conditions would be unacceptable from environmental considerations and are not likely to be accepted by downstream users of the Ganga.

One approach to the problem of the low flow of the Ganga grew out of the work of Revelle \& Herman (1972) and Lakshminarayana \& Revelle (1975) which has been labelled "The Ganges Machine". It is an approach based on groundwater development in the Ganga basin in conjunction with surface water.

Besides the limited possibilities of surface storage, there are at least five ways in which a portion of the monsoon flow could be stored underground. Infiltration into the water table in the monsoon season could be increased by (i) water spreading in the piedmont deposit north of the Terai belt of the springs and marshes; (ii) constructing bunds at right angles to the flow lines in uncultivated fields to slow down run-off and increase infiltration; (iii) pumping out the underground aquifers during the dry season in the neighbourhood of nullahs (natural drains) which carry water during the monsoon (Rama 1971); (iv) pumping out groundwater during the dry season along certain tributaries of the Ganga to provide space for groundwater; and (v) increasing seepage from irrigation canals during the monsoon season by extending the network of canals, distributaries, and water courses for kharif irrigation and pumping out this seepage 
water during the dry season. In addition, evaporation losses from the water table might be reduced by lowering it below the level of appreciable evaporation. Finally, it may be beneficial to export some monsoon water from the Basin to areas in the south and the west where irrigation could be extended if firm water supplies were available.

In table 1 we have estimated the likely increase in irrigation water supplies produced by some of these devices. A large increase could be obtained by constructing barrages and "leaky" canal systems for surface irrigation of a large part of the cultivated area, including an increased area of rice cultivation during the kharif season, and wells to recover the underground seepage during the rabi season. Recharge of aquifers along certain Ganga tributaries could provide an equally large increase of rabi irrigation supplies.

There is good reason to believe that in many places the underground aquifers are well-connected to the rivers and are highly permeable. For example, in one region where a groundwater survey was made (Pathak 1969) the seasonal contours of the water table on both sides of a large tributary show that this river is a drain which carries off perhaps $0.12 \times 10^{6}$ ha $\mathrm{m}$ of water that seeps into it during the dry months from the underground aquifers. If these contours could be reversed by large-scale pumping of the underground waters in the dry season, the aquifers could receive and store a large

Table 1. Possible future water budget for the Ganga plain

\begin{tabular}{|c|c|c|}
\hline \multirow[b]{2}{*}{ Source or sink } & \multicolumn{2}{|c|}{ Volume $\left(\times 10^{6}\right.$ ha $\left.\mathrm{m}\right)$ during } \\
\hline & $\begin{array}{c}\text { Low flow } \\
\text { season } \\
\text { (November } \\
\text { to June) }\end{array}$ & $\begin{array}{c}\text { High fiow } \\
\text { season } \\
\text { (July to } \\
\text { October) }\end{array}$ \\
\hline \multicolumn{3}{|l|}{ Supplies } \\
\hline Present average river flow at Bangladesh boundary & $7 \cdot 3$ & $28 \cdot 9$ \\
\hline Evapotranspiration from present surface storage and river diversion & 1.8 & 1.8 \\
\hline Evapotranspiration from present well irrigation (1968-1969) & $1 \cdot 3$ & 0.7 \\
\hline Additional surface storage (under construction or potential) & 1.5 & -1.5 \\
\hline Reduction of groundwater evaporation by pumping down watertable & 0.8 & \\
\hline Increased infiltration of rainfall by bunding in uncultivated areas & 0.7 & $-0 \cdot 7$ \\
\hline Potential additional underground storage & $6.0 \ddagger$ & $-6.0 \div$ \\
\hline Transfers out of basin (such as "Ganga-Cauvery Link”) & & $-1 \cdot 8$ \\
\hline Total supplies & $19 \cdot 4$ & $21 \cdot 4$ \\
\hline \multicolumn{3}{|l|}{ Uses and excess flows } \\
\hline Consumptive use in present irrigation (1968-1969) & $3 \cdot 1$ & $2 \cdot 5$ \\
\hline Consumptive use in potential additional irrigation & $9 \cdot 0$ & $6 \cdot 0$ \\
\hline $\begin{array}{l}\text { Diversion to Hooghly River at Farakka Barrage for } \\
\text { Calcutta maintenance }\end{array}$ & $2 \cdot 3 \ddagger$ & \\
\hline Needs for irrigation in Bangladesh & $1.8 \div$ & \\
\hline River navigation and waste disposal & $3 \cdot 2 \ddagger$ & \\
\hline Monsoon flow at Bangladesh boundary & & $12 \cdot 9^{*}$ \\
\hline Total uses and excess flows & $19 \cdot 4$ & $21 \cdot 4$ \\
\hline
\end{tabular}

$\ddagger$ See text. * Estimated by difference. 
part of the monsoon flow of the river. We believe that similar underground storage of river floodwater could be carried out along many tributaries of the Ganges.

It would be necessary to lower the water table at the beginning of the monsoon season to a greater depth than that required simply to produce the storage volume. Moreover, the aquifer directly under the river would need to be pumped down close to the average depth. In the rivers of the western part of the plain, where the dry season flow comes largely from groundwater seeping out of the river banks, the low flow discharge during the first year would be removed by the pumping, and thereafter the river would be virtually dry from November to June. Several years would be required to obtain the full storage potential. Each year the water table at the beginning of the monsoon season would be pumped deeper than the year before, until an equilibrium is ultimately reached.

\section{Pumping out groundwater during the low flow season}

For a rough estimate we may assume that along $3200 \mathrm{~km}$ of the system of the larger tributaries of the Ganga (about a quarter of the total length) large well fields could be constructed which would produce storage space by pumping out the groundwater during the low flow season. With well fields $6 \mathrm{~km}$ wide on either side of the river, the area covered would be $3.8 \times 10^{6}$ ha. If we assume that the well field capacity is 2.25 cumecs $/ \mathrm{km}$ (that is, 1.12 cumecs $/ \mathrm{km}$ of length on each side of the river) and the storage coefficient of the aquifer is 0.25 , then the water table will be lowered, on the average, about $12 \mathrm{~m}$ at the end of 8 months of continuous pumping. All the wells need not be of the same capacity. It is necessary only to design the well spacings and discharges in such a way that we pump out a trough of $12 \mathrm{~m}$ below the river bed. The method used for finding the depressions of the water table is given below.

The drawdown due to pumping in an aquifer is given by

$$
s=\frac{Q}{4 \pi T} \int_{r^{2} S / 4 T t}^{\infty} \frac{\exp (-u)}{u} \mathrm{~d} u,
$$

where the drawdown $s=h_{i}-h(\mathrm{~m}), h_{i}$ is the initial saturated thickness of the aquifer $(\mathrm{m}), h$ is the height of the water table during pumping $(\mathrm{m}), Q$ is the discharge $\left(\mathrm{m}^{3} /\right.$ day), $T$ is the coefficient of transmissibility $\left(\mathrm{m}^{2} / \mathrm{day}\right.$, $S$ is the storage coefficient (dimensionless), $t$ is time since pumping started (days), and $r$ is the distance from the pumping well (m).

Equation (1) holds strictly only for a confined aquifer which is isotropic and homogenous. However, it can be used for an unconfined water table aquifer (as in the present case) provided drawdown is small compared with the original saturated thickness of the aquifer. In the Ganga plain the aquifers are quite thick, and the drawdown of the water table will be small compared to the initial saturated thickness of the aquifer; consequently, we can apply (1), which also has other assumptions involved in its derivation. Revelle \& Herman (1972) showed that although these assumptions are not strictly valid in the present case, the equation can still be used to give a fairly good solution.

Equation (1) is the solution of the differential equation

$$
\frac{\partial^{2} h}{\partial r^{2}}+\frac{1}{r} \frac{\partial h}{\partial r}=\frac{S}{T} \frac{\partial h}{\partial t}
$$




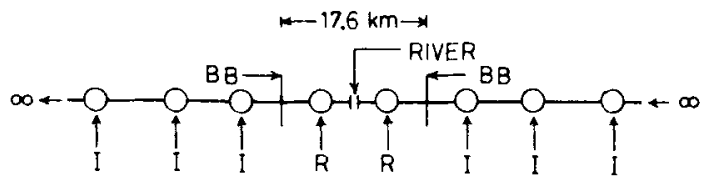

Figure 1. Location of real and image well groups. BB, barrier boundary; $\mathbf{R}$, real well group centre; I, image well group centre

subject to certain simple boundary conditions. Since (2) is linear, the superposition principle can be used to find the solution when more than one well is being pumped in the aquifer. Equation (1) is obtained assuming that the aquifer is really infinite. If we have boundaries, we must use the method of images

In the present calculation we have assumed that there is a natural groundwater divide at a distance of $8 \mathrm{~km}$ on either side of the river. This is approximately true for many of the tributaries that feed the main tributaries of the Ganga. The natural groundwater divide acts as an impervious barrier. The presence of the river itself can be ignored in the computations, since during the dry season the quantity of flow in many Ganga tributaries will be small compared to the quantity of pumping. Grouping the wells in pumping centres, we will have the real and image wells shown in figure 1 . Because of the assumed existence of an impervious boundary on either side of the river, there will be an infinite number of images. However, only a few need to be considered, since the effect of image wells very far off will be small near the river.

Equation (1) is applied repeatedly for all the real and image wells, and we obtain a lowering of the water table, on the average, of about $12 \mathrm{~m}$ at the real wells.

\section{Recharge of groundwater mound by monsoon flow}

When pumping stops at the end of the dry season there is some flow into the trough from the sides. It is, therefore, assumed that we have a net trough with an average depth of $10 \mathrm{~m}$ to be partly filled by monsoon flow in the river.

The growth of the groundwater mound resulting from infiltration of the monsoon flow in the river is computed by using the following equations given by Hantush (1967),

$$
\begin{aligned}
h^{2}= & h_{1}^{2}+\frac{W T}{K S} t\left\{2-4 i^{2} \operatorname{Erfc}(L-x)(4 T t / S)^{-1 / 2}\right. \\
& \left.-4 i^{2} \operatorname{Erfc}(L+x)(4 T t / S)^{-1 / 2}\right\} \quad \text { for } x<L, \\
h^{2}= & h_{1}^{2}+\frac{W T}{K S} t\left\{4 i^{2} \operatorname{Erfc}(x-L)(4 T t / S)^{-1 / 2}\right. \\
& \left.-4 i^{2} \operatorname{Erfc}(L+x)(4 T t / S)^{-1 / 2}\right\} \quad \text { for } x>L,
\end{aligned}
$$


where the symbols other than the ones already used are: $W$, recharge rate through the bed of the river ( $\mathrm{m} / \mathrm{day}) ; K$, coefficient of the permeability in the aquifer (m/day); $t$, time during which recharge takes place (days); $L$, half width of river $(\mathrm{m}) ; x$, distance from centre of river $(\mathrm{m})$; and

$$
\begin{aligned}
& \operatorname{Erf}(x)=\frac{2}{\pi^{1 / 2}} \int_{0}^{x} \exp \left(-\xi^{2}\right) \mathrm{d} \xi \\
& \operatorname{Erfc}(x)=1-\operatorname{Erf}(x) ; 4 i^{2} \operatorname{Erfc}(x)=\operatorname{Erfc}(x)-2 x i \operatorname{Erfc}(x)
\end{aligned}
$$

Since (3) and (4) are implicit, a trial and error procedure or a graphical method has to be adopted for the solution. For example, assume $t=15$ days. Then, using $T=4650 \mathrm{~m}^{2} /$ day, $L=150 \mathrm{~m}, W=0.61 \mathrm{~m} /$ day, $K=15.2 \mathrm{~m} /$ day, $S=0.25, h_{i}=300 \mathrm{~m}$, and $t=15$ days, we get $(4 T t / S)^{\frac{1}{2}}=1055 \mathrm{~m}$ and $L /(4 T t / S)^{\frac{1}{2}}=0 \cdot 144$. From (3) we find

$$
h^{2}=(300)^{2}+\left(\frac{0 \cdot 61}{15 \cdot 2} \times \frac{4650}{0 \cdot 25} \times 15\right)(0 \cdot 56)=96,270 \mathrm{~m}^{2},
$$

Therefore, $h=310 \mathrm{~m}$ and $h-h_{i}=10 \mathrm{~m}$.

Thus the time for the water to rise $10 \mathrm{~m}$ at the centre of the recharging strip is 15 days.

The height of the groundwater at a distance of $600 \mathrm{~m}$ from the centre of the river can be computed as follows:

$$
\begin{aligned}
& (x-L)(4 T t / S)^{-1 / 2}=450 / 1055=0.43 \\
& (x+L)(4 T t / S)^{-1 / 2}=750 / 1055=0.72
\end{aligned}
$$

Using (4) we obtain

$$
h^{2}=(300)^{2}+\left(\frac{0 \cdot 61}{15 \cdot 2} \times \frac{4650}{0.25} \times 15\right)(0 \cdot 35-0 \cdot 14)=92,350 \mathrm{~m}^{2} .
$$

Therefore, $h=303.5 \mathrm{~m}$ and $h-h_{i}=3.5 \mathrm{~m}$. Similarly at $1500 \mathrm{~m}$, we obtain

$$
\begin{aligned}
& h^{2}=(300)^{2}+\left(\frac{0.61}{1512} \times \frac{4650}{0.25} \times 15\right)(0.016-0.005)=90,123 \mathrm{~m}^{2} \\
& h=300 \cdot 2 \mathrm{~m} \text { and } h-h_{1}=0.2 \mathrm{~m} .
\end{aligned}
$$

Thus, assuming that the rate of recharge is $0.61 \mathrm{~m} /$ day, which is rather conservative, the height of the water mound at the end of 15 days will be $3.5 \mathrm{~m}$ at a distance of $600 \mathrm{~m}$ and $0.2 \mathrm{~m}$ at a distance of $1500 \mathrm{~m}$. From this we can compute the quantity of monsoon water abstracted as $1 \times 10^{6}$ ha $\mathrm{m}$. After 15 days there will still be some recharge, because some of the bank flow from the river will continue to fill the trough. Thus, during the first year of operation a little more than $1 \times 10^{6}$ ha $\mathrm{m}$ will be extracted from the monsoon flow. When this is spread over the groundwater basin $17.5 \mathrm{~km}$ wide, it will raise the water table by $0.75 \mathrm{~m}$. To this we may add a rise of the water table by $0.6 \mathrm{~m}$ caused by $15 \mathrm{~cm}$ of net rainfall infiltrating to the water table. Thus, at the beginning of 
the second year of operation the water table will be about $8.6 \mathrm{~m}$ below the level at the beginning of the first year.

During the second year of operation, the water table will be lowered by $10 \mathrm{~m}$ to a depth of about $18.6 \mathrm{~m}$ before the monsoon flow begins. The time taken to raise the water table $18.6 \mathrm{~m}$ at the centre of the river bed during the monsoon works out to 33 days. At this time the height of the groundwater mound will be $7.5 \mathrm{~m}$ at a distance of $600 \mathrm{~m}$ and $1.5 \mathrm{~m}$ at a distance of $1500 \mathrm{~m}$. The total quantity of monsoon water extracted will be about $2 \times 10^{6}$ ha $\mathrm{m}$, again ignoring the contribution from bank flow. This will raise the water table by about $1.5 \mathrm{~m}$. Adding about $0.6 \mathrm{~m}$ due to infiltration of rainfall, the depth of the water table at the beginning of the dry season in the following year will be $16.5 \mathrm{~m}$ below the initial level.

During the third year of operation, this will again be lowered by $10 \mathrm{~m}$, leaving the water table at a depth of about $26.5 \mathrm{~m}$ at the beginning of the monsoon. The time taken for the water table under the river to rise $26.5 \mathrm{~m}$ is about 70 days. At this time the height of the groundwater mound will be $15 \mathrm{~m}$ at a distance of $600 \mathrm{~m}, 5 \mathrm{~m}$ at a distance of $1500 \mathrm{~m}$, and $0 \mathrm{~m}$ at a distance of $3000 \mathrm{~m}$. Thus, the amount of water extracted from the monsoon flow, ignoring the contribution from bank flow, will be about $6 \times 10^{6}$ ha m. At the end of the monsoon the water table will be at an average depth of about $22 \mathrm{~m}$ over the cross section of $17.5 \mathrm{~km}$.

By similar computation, we can show that during the fourth year of operation the depth of the water table at the end of the pumping season will be $32 \mathrm{~m}$, and in the 120 days of the monsoon season we will extract from the monsoon about $9 \times 10^{6}$ ha $\mathrm{m}$. The depth of the water table at the end of the monsoon will be about $25 \mathrm{~m}$ below the initial level 4 years earlier.

From the following year onwards, the water table will be stabilized at these levels by pumping out a quantity equal to consumptive use, surface drainage and return infiltration to the groundwater table.

Figure 2 shows the growth of the groundwater mound under uniform recharge from the river for the stated values of the parameters. Because different scales have been used in the horizontal and vertical directions, the slope of the water table appears to be steep.

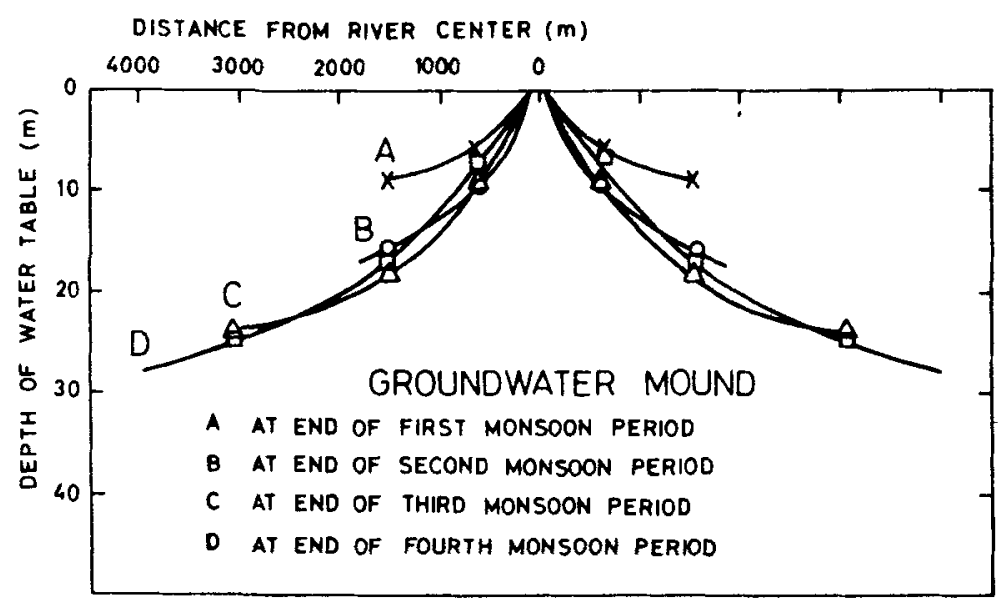

Figure 2. Growth of groundwater mound under uniform recharge from river. 
Actually its profile will be very flat. For instance, at the end of the first monsoon period the slope will be approximately 1 to 170 ; at the end of the fourth monsoon period it will be approximately 1 to 140 . We can therefore use the bank storage equations given by Cooper \& Rorabaugh (1963) for a horizontal water table, as shown in the next section.

With any particular set of assumed parameters, equilibrium will be reached in the number of years required to lower the water table to a depth such that 120 days (the length of the monsoon season) will be required for the inflitration mound to reach the bed of the river. For example, assuming a storage coefficient of $0 \cdot 15$, a transmissibility of $2800 \mathrm{~m}^{2} /$ day, and a pumping rate of 1.35 cumecs $\mathrm{km}^{-1}$, an equilibrium depth of $35 \mathrm{~m}$ at the end of the monsoon season will be reached in about 12 years. From that time onward, $6 \times 10^{6}$ ha $\mathrm{m}$ will be stored each year.

During the monsoon season the rivers in northern India always carry some water, with flood peaks occurring after every heavy storm. Thus, even if the duration of the flood wave is short, say 6 to $12 \mathrm{hr}$ in the smaller streams (longer in bigger tributaries), recharge will continue under the lesser flow that prevails before and after its passage. Hence we can assume that about 120 days are always available for recharge during the monsoon season.

\section{Advantages of aquifer storage}

\subsection{Flood amelioration}

During the flood wave there will be much more bank storage than there is now along the tributaries where the water table has been lowered by pumping. This will supplement the aquifer storage described above in reducing downstream flooding. The amount of bank storage can be computed from the equations of Cooper \& Rorabaugh (1963).

Assuming a flood duration of 3 days, a flood crest of $3 \mathrm{~m}$, aquifer transmissibility of $4650 \mathrm{~m}^{2} /$ day, and a storage coefficient of 0.25 , the amount of bank storage 2 days after the beginning of the flood will be $2.3 \times 10^{5} \mathrm{~m}^{3} / \mathrm{km}$. This temporary bank storage is $50 \%$ of the water entering the aquifer during the same 2-day period; $75 \%$ of the bank storage will return to the river during the following 7 days.

\subsection{Use of stored monsoon waters in irrigation}

The area to be irrigated with the pumped waters would be larger than that of the well fields. Assuming $6 \times 10^{6}$ ha $\mathrm{m}$ of storage from the monsoon flow, and adding the rainfall infiltration of $0.15 \mathrm{~m}$, the gross irrigated area would be 17.5 to $19 \mathrm{~m}$ ha. Here we assume that an amount of water equal to $10 \%$ of consumptive use by evapotranspiration is allowed for drainage to maintain a salt balance, or alternatively the original dry season flow of the river is returned downstream of the well fields in order to maintain the low flow. If the irrigated areas, including the zone of intense pumping, were located in strips along both sides of the rivers used in the scheme, the average width on each side of the rivers would be roughly 27 to $30 \mathrm{~km}$.

Allowing for $20 \%$ return infiltration of the pumped water, the total pumping from the irrigated area during the dry season is about $10.5 \times 10^{6}$ ha $\mathrm{m}$, requiring a total well capacity of around 5000 cumecs. If the well fields are $6 \mathrm{~km}$ wide on either side of the river, more than half the net volume pumped would need to be transported to the outer 
21- to 24-km strip in surface conveyance channels. Since unlined channels inevitably leak into the ground a considerable fraction of the water they carry, this surface distribution system could, with proper management, also be used as a groundwater storage mechanism. For example, if the channels extended to the river, they could be used as inundation canals for irrigation during the monsoon season, and $30-50 \%$ of the water carried in them would be expected to seep downward to the aquifer.

\section{Possible tributaries for monsoon storage}

Table 2 shows possible river reaches along which the underground storage scheme for the monsoon waters might be used, and table 1 shows a possible future water budget for the Ganga plain. It will be seen that in the western tributaries the initial dry-season flow would be about $25 \%$ of the water coming from the rivers into the aquifer. A portion of pumped water would be needed for water supply and waste disposal for cities and towns along these rivers; return flows from irrigation could also be used for waste disposal. In either case, conveyance channels or pipes for the pumped water would be required. In the central and eastern plain, the dry-season flow probably comes largely from the Himalayas and equals 42 to $77 \%$ of the quantity of stored monsoon water. For economy in pumping and ease in maintaining the low flow water supplies for cities and towns, it would probably be desirable to construct diversion barrages upstream of the well fields and lined channels to carry the diverted water downstream of these fields.

Table 2. Possible river reaches for underground storage of monsoon flows

\begin{tabular}{|c|c|c|c|c|c|}
\hline \multirow[b]{2}{*}{ River } & \multirow{2}{*}{$\begin{array}{l}\text { Length } \\
\text { of well } \\
\text { fields } \\
(\mathbf{k m})\end{array}$} & \multicolumn{2}{|c|}{ Monsoon flow ( $\times 10^{6}$ ha $\left.\mathrm{m}\right)$} & \multirow{2}{*}{$\begin{array}{c}\text { Dry- } \\
\text { season } \\
\text { flow } \\
\left(\times 10^{6}\right. \\
\text { ha m) }\end{array}$} & \multirow{2}{*}{$\begin{array}{l}\text { Ratio of } \\
\text { dry- } \\
\text { season } \\
\text { to stored } \\
\text { flow }(\%)\end{array}$} \\
\hline & & $\begin{array}{l}\text { Stored } \\
\text { under- } \\
\text { ground }\end{array}$ & $\begin{array}{l}\text { Remain- } \\
\text { ing in } \\
\text { river }\end{array}$ & & \\
\hline Ganga to Yamuna & 720 & $1 \cdot 3$ & $0 \cdot 1$ & $0 \cdot 3$ & 23 \\
\hline Ramganga & 560 & 1.0 & 0.1 & $0 \cdot 2$ & 20 \\
\hline Yamuna system & 1440 & 2.6 & $0 \cdot 3$ & 0.7 & 27 \\
\hline Gomti and Sai & 610 & $1 \cdot 1$ & 0.1 & 0.3 & 27 \\
\hline Gagra, Sarda, and Rapti & 1280 & $2 \cdot 3$ & $3 \cdot 2$ & 1.2 & 52 \\
\hline Son & 640 & $1 \cdot 2$ & 1.0 & 0.5 & 42 \\
\hline \multicolumn{6}{|l|}{ Buhri, Gandak and } \\
\hline Baghmati & 720 & $1 \cdot 3$ & $3 \cdot 2$ & 1.0 & 77 \\
\hline \multicolumn{6}{|l|}{ Below the Kosi, including } \\
\hline Mahananda & 400 & 0.7 & $1 \cdot 1$ & 0.4 & 57 \\
\hline Totals & 6370 & 11.5 & $9 \cdot 1$ & $4 \cdot 6$ & 42 \\
\hline Sum of 1 to 4 & 3330 & $6 \cdot 0$ & 0.6 & 1.5 & 25 \\
\hline Sum of 5 to 8 & 3040 & $5 \cdot 5$ & $8 \cdot 5$ & $3 \cdot 1$ & 56 \\
\hline
\end{tabular}

Note:-Estimated monsoon and dry-season flows are based on UN data. 


\section{Costs and benefits of the storage scheme}

\subsection{Power requirements for pumping stored monsoon waters.}

Assuming an average pumping lift of $30 \mathrm{~m}$, the net electrical energy required to pump $10.5 \times 10^{6}$ ha $\mathrm{m}$ would be $8.75 \times 10^{9} \mathrm{kWh}$. With an overall efficiency of $67 \%$ including transmission losses, the energy required at the generating plant would be 13 $\times 10^{9} \mathrm{kWh}$, corresponding to an installed power capacity of $3000 \mathrm{MW}$ at $50 \%$ load factor.

The electrical power requirement could be supplied by pit head electric generating plants in the Raniganj-Jharia coal fields in Bihar, or by utilizing a small fraction (possibly less than $15 \%$ ) of the enormous potential hydroelectric capacity of Nepal.

All the methods we have described for underground storage of monsoon waters would involve use of electric or diesel power for pumping. Because of the greater depth of pumping, the energy requirements for the river storage scheme would be larger than for other methods, but the ratio of benefits to costs would still be high.

\subsection{Annual costs and benefits of the storage scheme}

At $\$ 0.02$ per $\mathrm{kWh}$, the annual power cost would be $\$ 260$ million, or about $\$ 14.50$ per gross irrigated hectare. At $\$ 0.005$ per $\mathrm{kWh}$, the power cost would be $\$ 3.65$ per gross irrigated hectare.

Construction costs of tube wells per unit of capacity diminish with increasing well capacity. Compared with larger wells, the maximum cost should be for wells pumping 0.03 cumecs. Assuming that the cost is $\$ 10,000$ per well, the total cost for 170,000 wells would be $\$ 1.7$ billion. Amortized over 10 years at $8 \%$, the annual costs of well construction would be roughly $\$ 14.00$ per gross irrigated hectare. To these fuel and capital costs should be added the cost of land for the tube wells and the drainage conveyance channels, the cost of constructing these channels, and the labour costs for maintenance and operation of the system. With our present information we are unable to estimate these costs, but we believe they should be less than $\$ 15$ per year per gross irrigated hectare.

The total annual costs would thus be about $\$ 40$ to $\$ 45$ per gross irrigated hectare. With adequate water management and proper use of fertilizers and other inputs, it would be possible to obtain high productivity from high-yielding crop varieties on the irrigated fields in contrast to the present yields from traditional varieties, which must be used on unirrigated lands. The gross value of cereal crops would be of the order of $\$ 500$ per hectare, ten times the annual costs of irrigation water supplies.

Of equal importance would be the increased food production from the newly irrigated lands. For the entire Ganga plain, the storage of monsoon waters along tributaries by the pumping scheme we have proposed would provide a basis for an increase in production of $55 \times 10^{9} \mathrm{~kg}$ per year. All storage methods combined, together with increased kharif irrigation from canals, would give more than $110 \times 10^{9} \mathrm{~kg}$ above present production, enough by itself to provide a greatly improved diet for 400 million people.

In table 1 we estimate that $6 \times 10^{6}$ ha mould be used for irrigation during the kharif season of monsoon rainfall and high river flows. The necessity for irrigation in this season is due both to the large variation from year to year in total monsoon rainfall and 
to the intraseasonal irregularity of the rainfall. In many areas, water supplies for monsoon irrigation could be obtained by construction of barrages across the Ganga tributaries, which will divert waters into systems of canals, distributaries, and water courses. About 35 to $50 \%$ of this water will seep into the ground and can be used for well irrigation during the dry season. Thus, the possibilities for total underground storage are much larger than our estimates of the storage than can be obtained by pumping out the aquifers along tributaries. The total potential irrigation in the Ganga plain may be limited by the area of irrigable land rather than the water supply.

\section{Need for further investigation}

The choice between systems for storage of underground water will vary from region to region, and possibly with the stage of development of the integrated system of surface and groundwater irrigation. Further detailed field investigations and systematic analysis are required to determine the choice and sequence of investments for irrigation. Among the factors which should be considered are: the effects of sediment transportation and deposition which might reduce infiltration rates from the rivers, the possible hazards of subsidence resulting from lowering the water table, and possible ecological effects. Special attention should be paid to design and construction of irrigation projects that are compatible with the long-range objectives of storing monsoon waters and maintaining the present volume of flow during the dry season. Projects that are incompatible with these objectives should not be initiated.

\section{Appendix. A Consumptive use of irrigation water}

The consumptive uses of irrigation water as of 1968-69 are computed as follows: 4.15 $\times 10^{6}$ ha are irrigated from storage reservoirs and canal systems, $1.55 \times 10^{6}$ ha from tanks and other minor surface storage, and $4.41 \times 10^{6}$ ha from wells. This gives a total net irrigated area of $10.1 \times 10^{6}$ ha. Assuming that the depth of water consumed in field evapotranspiration and drainage is $45 \mathrm{~cm}, 20 \%$ of water diverted for irrigation from large reservoirs and canal systems is lost by evaporation, mainly in the reservoirs, and $90 \%$ is lost from tanks, the total consumptive use is $3.6 \times 10^{6}$ ha $\mathrm{m}$ for surface irrigation and $2 \times 10^{6}$ ha $\mathrm{m}$ from wells. The allocation of irrigation waters between kharif and rabi seasons is our best estimate based on irrigation practices in the Ganga plain. It is generally recognized that present irrigation supplies are inadequate. In considering modification of present systems and future irrigation, we have assumed that average field evapotranspiration and drainage will be $50 \mathrm{~cm}$, including nonbeneficial uses. For $37.5 \times 10^{6}$ gross irrigated hectares, consumptive use plus other evaporation losses would be about $20.6 \times 10^{6}$ ha $\mathrm{m}$.

The average amount of water evaporating from the water table is probably between 2 and $3 \mathrm{~cm}$. A reduction of $2 \mathrm{~cm}$ over an area of $40 \times 10^{6}$ ha might be obtained if the average depth to the water table were lowered by a few metres. This should not seriously interfere with the seepage of groundwaters into the rivers, which is the source of much of the river flows during the dry season. We estimate that construction of a sufficient number of low bunds at right angles to the flow lines in uncultivated areas might increase rainfall infiltration by $10 \%$ or $0.7 \times 10^{6}$ ha m. 


\section{References}

Cooper H H, Rorabaugh M J 1963 U.S. Geological Survey, Water Supply Paper 1536-1, p. 343

Economic Commission for Asia and the Far East 1966 A Compendium of major international rivers in the ECAFE regions, Water Resources Series No. 29, United Nations, New York

Hantush M S 1967 Water Resources Res. 3:227

Irrigation Commission of India 1972, Report of the Irrigation Commission, Ministry of Irrigation and Power, New Delhi, Vol 1-3.

Lakshminarayana V, Revelle R 1975 Science 188: 541-549

Pathak B D 1969 in Groundwater studies in arid and semi-arid regions, Proc. Symp. Roorkee, India, p. 55 Rama 1971 Science Today, September

Revelle R, Herman T 1972 Some possibilities for international development of the Ganges-Brahmaputra basin, Res. Report, Harvard University Centre for Population Studies, Cambridge, Mass, USA 